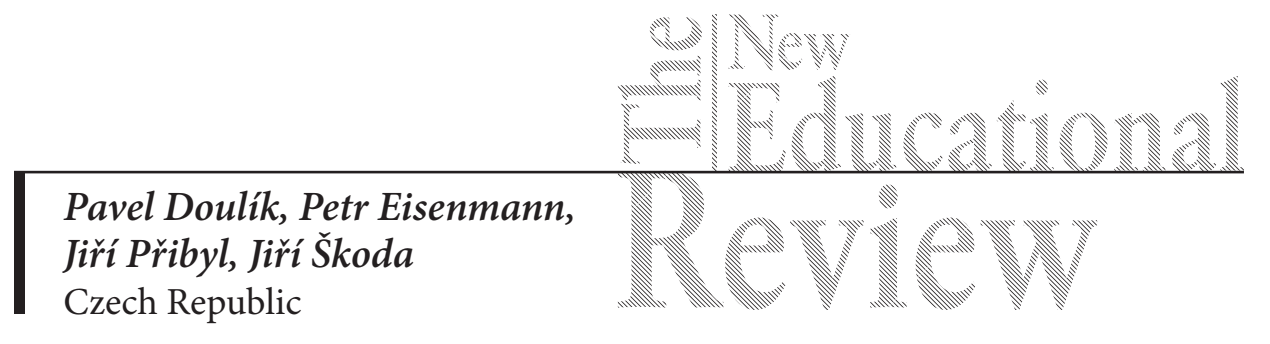

\title{
Unconventional Ways of Solving Problems in Mathematics Classes
}

DOI: 10.15804/tner.2016.43.1.04

\begin{abstract}
The contribution enquires into possibilities of application of the heuristic methods in the teaching process, specifically its applications during the classes of mathematics in grammar school. In the frame of the research the influence was monitored of the unconventional way of solving problems during classes of mathematics in relation to the evaluation of educational advancements. Furthermore, pupils evaluated their attitude towards mathematical study including their viewpoint on problematic exercises in maths and the successfulness of solving these mathematical exercises was also evaluated. The results of the experimental group were compared to the same areas in the control group.
\end{abstract}

Keywords: heuristic method of teaching, problem-based learning, inquiry-based learning, constructivist theories, learning activity management

\section{Introduction}

A number of research studies in didactics have, in the last 5-10 years, tackled the issue of problem-oriented strategies within teaching with the strategies structured under a variety of names as well as in different subtleties: problem-based learning, heuristic teaching, research-oriented teaching, learning-activating methods, etc. Introducing problem teaching/learning into the real procedure of education often occurs spontaneously, unsystematically, and is backed up by teachers' enthusiasm rather than their deeper understanding of the issue background of problem-oriented strategies in learning activity management. 
Satisfactory answers to questions asked in relation to problem-based teaching and learning can only be offered by a long-term, thought-through and well-organized implementation of the above-mentioned strategies, and it should not be limited to specific - and in principle isolated - educational contents only, but is to focus on creating pupils' general competences aiming at the very usage of effective strategies in problem-solving as well as developing self-regulatory and autodidactic skills in learning individuals. The presented paper aims at introducing selected results of particular long-run experimental teaching, concerning solving problems in mathematics with the use of heuristic strategies.

\section{Theoretical background}

Approaches to teaching focused on introducing problems and solving them can hardly be considered a unique and whole paradigm with its own theoretical framing. Problem-solving learning methods are understood to be a specific variety of heuristic teaching approaches. Such approaches are to be deduced from Socrates' Maieutic method, which is dialogue-based, and concerns features significant at a personal level. Pupils are exposed to known units in a new context, i.e., confronted with their ideas and transposed to a contradiction (aporia). This cognitive conflict can be approached as a problem. Excluding individual hypotheses, the pupil gradually reaches their knowledge and axioms on which the knowledge has been based (Kanakis \& Chatzidimou, 1980).

Heuristic teaching methods are not to be limited to teaching through dialogue. In a broader context, they cover larger complexes of learning activities, including problem identification, formulation of hypotheses, asking questions, observation, experimenting, collecting data and its evaluation, comparison, discussion, generalization, result verification, etc. (Boud \& Felletti, 1997). The wide spectrum of heuristic teaching methods, in its complexity, comprises other specific approaches such as problem-based learning and research-oriented teaching along with inquiry-based learning. Among the above-mentioned approaches, we trace many analogies and thus define several basic features found in these attitudes: the core of the teaching-learning process is the student's own activity; the teacher's function is that of a facilitator of the educational process, and they also, in cooperation with their pupils, set problem issues, incite cognitive conflicts within students' preconceptions and reality, set conditions for their individual observation, experimenting, tackling information, correct pupils' possible errors and help them verify results or help them solve problems the students have encountered. The aspects mentioned 
are rooted in educational constructivism. Constructivism is considered as a major theoretical basis in pupils' learning activity management applied within heuristic approaches. A problem-solving individual faces their confrontation and uses their personal experience and their own cognitive processes in the teaching-learning situation. The determining element in the comprehension of reality is the learner's personality, and they invent their particular reality through their learning activity (McInerney \& McInerney, 1998).

The Czech didactics of mathematics used the term of so-called problem-based learning in the 1960s. The leading personality in the branch of mathematics didactics of that time was Jan Vyšín, whose ideas of problem-based learning were followed by other writers developing the constructivist approach in teaching mathematics. Let us point out František Kuřina (e.g., Kuřina 2011) and Milan Hejný (Hejný and Kuřina, 2009). Nada Vondrová (Stehlíková, 2007) and Darina Jirotková (Jirotková, 2010) are today's representatives of the constructivist approach in the didactics of mathematics.

It has been generally approved that efficient mathematics teaching consists in solving problems, as it is referred to in the curricula files (Jeřábek, Lisnerová, Smejkalová, \& Tupý, 2013). The issues of solving problems have been the subject of research for a long time and has been viewed from many perspectives (for more detail cf., Silver, 1985).

The student's ability to acquire a selected heuristic strategy depends on not only the teaching-learning environment, but also the inner dispositions of the learner, mainly his or her attitude to problem solving with the use of heuristic strategies. Pajares \& Kranzler (1995) state that the generally accepted truth of the learner's self-confidence in problem solving is positively reflected in the very ability to solve problems and helps them lower their mathematical anxiety.

\section{Practical part}

\section{Research design}

The conducted research study was based on long-term and systematic application of problem-solving learning in mathematics classes at grammar school. Within our research, three causal research problems were stated:

RP1: What is the influence of alternative methods of problem-solving on educational processes when applied while teaching mathematics at grammar school? 
RP2: What is the influence of alternative methods of problem-solving on longitudinal changes in commonly used problem-solving strategies in mathematics at grammar school?

RP3: What is the influence of alternative methods of problem-solving on the learners' attitudes to maths education and problem-solving at grammar school?

The three formulated research problems consequently led to the following research objectives:

1. Find out what the students' evaluation of educational processes used by their teachers in mathematics classes in the experimental and control groups are.

2. Find out what longitudinal changes take place within applying strategic maths problems solutions after systematic implementation of problem-based learning methods has ceased.

3. Find out what the learners' attitudes to maths education in the experimental and control groups are.

Tackling research problems and fulfilling the stated objectives of the research study, a quantitative research design with a quasi-experimental base was decided on. The class with long-term unconventional problem-solving methods used was the experimental group. The control group was, thus, the class with traditional teaching methods, with a lack of systematic problem-solving teaching methods.

On the basis of the determined research objectives, research hypotheses were formulated:

HO1: Using educational processes in teaching mathematics positively inciting individual problem-solving is highly appreciated by the learners in the experimental group rather than the learners in the control group.

HO2: Immediately after ceasing the systematic implementation of problem-solving learning methods in mathematics classes, the students use heuristic strategies more often than they will do within half a year after the problem-solving teaching has stopped.

HO3: The students in the experimental group show better attitudes to mathematics education along with solving problems compared to the control group learners.

Verification of the research hypotheses with the use of adequate inductive methods of statistical analysis of data was realized at the significance level $\alpha=0.05$. Comparing data obtained by interpreting individual items on the interval measurement level, F-test was first used, and consecutively an adequate type of t-test to set congruous and incongruous variance. To compare data obtained through evaluating items at the nominal measurement level, chi-squared statistics test of independence was used. 
The experiment took place between September 2012 and February 2014 at Jan Neruda Grammar School, Prague (Gymnázium Jana Nerudy v Praze). The participating 20 students were 16 years old when the experiment started. The class curriculum does not belong to any specific branch of study (specialization). Jiří (aged 34, with 8 years of teaching experience) is a maths teacher for the mentioned group of students. In 16 months the learners were introduced to a selection of heuristic problem-solving strategies through solving problems, where the heuristic problem-solving strategies were the most efficient. The control group was designed to resemble the experimental group in as many features as possible (sample size, average of mathematics performance, etc.).

To realize the research study, two research tools were used - a questionnaire and a didactic test.

The educational procedures questionnaire used is a non-standardized research tool designed by the authors of this article. It consists of 26 entries that can be divided into two categories depending on their construct as follows:

- Entries 1-21 were constructed using a Likert scale within the interval measurement principle. These entries came to existence through adapting the observation protocol focusing on the concepts of teaching and evaluation. The scales are five-point, rated from 1 to 5 where value " 1 " represents a negative answer to a given question, disagreement with a given statement or zero incidence of the phenomenon; and where value " 5 " represents agreement, a positive stance or high frequency of occurrence.

- Entries 22-26 were constructed using the nominal measurement principle, with the respondent selecting the one that best represents their answer from the varieties suggested.

Considering the focus content of individual questionnaire entries, a selection of five item groups based on the following can be elicited:

1. evaluating work with educational content,

2. evaluating learners' class activity management in mathematics classes,

3. evaluating feedback information within mathematics classes,

4. evaluating the attitude towards mathematics as a school subject,

5. evaluating approaches to solving mathematics problems.

The experimental group students wrote a didactic test at the end of the teaching experiment and also eight months after the experiment had ceased; the test included eight problems. In the text to follow, we refer to these particular tests as final and retention tests. All the problems in the written tests were evaluated on the grounds of successful solutions to a given problem. A successful problem solution in all three tests was not strictly linked to unconditional 
content-of-teaching knowledge which had been discussed in class between September 2012 and June 2014.

\section{Research study evaluation}

Data evaluation was carried out with respect to the research hypotheses formulated. First, let us concentrate on items referring to the evaluation of dealing with the teaching content. The experimental group's $\left(\mathrm{x}^{\mathrm{o}} \mathrm{EXP}\right)$ answers in their arithmetic mean were tabulated; the control group's answers in their arithmetic mean $\left(\mathrm{x}^{\mathrm{o}}{ }_{\mathrm{REF}}\right)$; the value of test criteria in $t$-test $(t)$; the value of observed level of significance in test criteria $(\mathrm{P})$ (Table 1$)$.

Table 1. Respondents' answers evaluation of entries tackling reactions to teaching-content

\begin{tabular}{|c|c|c|c|c|c|}
\hline Item & $\mathbf{X}^{\mathbf{0}}$ EXP & $\mathbf{X}^{\mathbf{o}}$ REF & $\mathrm{t}$ & $P$ & Comparison \\
\hline $\begin{array}{l}\text { Does the teacher refer to your math knowl- } \\
\text { edge acquired in previous maths learning? }\end{array}$ & 3.92 & 4.04 & -0.632 & 0.529 & $\mathrm{X}^{\mathrm{o}} \mathrm{EXP}=\mathrm{X}^{\mathrm{o}}$ REF \\
\hline $\begin{array}{l}\text { Does the teacher refer to your previous } \\
\text { knowledge acquired in other school } \\
\text { subjects? }\end{array}$ & 1.71 & 2.08 & -2.762 & $3.45 .10^{-3}$ & $\mathrm{X}^{\mathrm{o}}{ }_{\mathrm{EXP}}<\mathrm{X}^{\mathrm{o}} \mathrm{REF}$ \\
\hline $\begin{array}{l}\text { Are there tasks set, where you have to use } \\
\text { other sources of information? }\end{array}$ & 3.00 & 1.48 & 7.076 & $1.21 .10^{-10}$ & $\mathrm{X}^{\mathrm{o}}{ }_{\mathrm{EXP}}>\mathrm{X}^{\mathrm{o}}{ }_{\mathrm{REF}}$ \\
\hline
\end{tabular}

The teacher of the experimental group assigns tasks considerably more often, so the pupils need to use other sources of information and not their textbooks only; other sources include the Internet, encyclopaedias, computer databases, etc. Conversely and statistically considerably less often, the experimental group's teacher links the students' knowledge previously acquired in other subjects to the current teaching content. Heuristic strategies (in problem-solving) encourage learners to use different ways of thinking rather than relying on cross-curricular knowledge.

We introduced the evaluation of the results to the students' answers in both groups, concentrating on the learners' evaluating their pupils' learning activity management (Table 2).

Such teaching-learning activities, typical of constructivist and education-centred strategies, were significantly more often appreciated by the respondents in the experimental group; dialogues between teacher - learner as well as learner(s) - learner(s) were applied, methods of punishment were less frequent and we could notice that the teacher paid more attention to gifted pupils. 
Table 2. Respondents' answers evaluation of entries tackling reactions to managing students' learning activities

\begin{tabular}{|c|c|c|c|c|c|}
\hline Item & $\mathbf{X}^{\mathbf{o}}$ EXP & $\mathbf{X}^{\mathbf{o}}$ REF & $t$ & $\mathrm{P}$ & Comparison \\
\hline $\begin{array}{l}\text { Does the teacher implement dialogue in } \\
\text { classroom communication? }\end{array}$ & 3.66 & 3.29 & 1.741 & 0.042 & $\mathrm{X}^{\mathrm{o}}{ }_{\mathrm{EXP}}>\mathrm{X}^{\mathrm{o}}{ }_{\mathrm{REF}}$ \\
\hline $\begin{array}{l}\text { Are students allowed to discuss problems } \\
\text { among themselves? }\end{array}$ & 3.00 & 2.16 & 5.506 & $1.53 .10^{-7}$ & $\mathrm{X}^{\mathrm{o}}{ }_{\mathrm{EXP}}>\mathrm{X}^{\mathrm{o}}{ }_{\mathrm{REF}}$ \\
\hline $\begin{array}{l}\text { Are students independent in their class } \\
\text { work or is it only incited by the teacher? }\end{array}$ & 3.62 & 3.39 & 1.261 & 0.210 & $\mathrm{X}^{\mathrm{o}} \mathrm{EXP}=\mathrm{X}^{\mathrm{o}} \mathrm{REF}$ \\
\hline $\begin{array}{l}\text { Does the teacher praise for achievement } \\
\text { in class? }\end{array}$ & 3.82 & 3.58 & 1.386 & 0.169 & $\mathrm{X}^{\mathrm{o}} \mathrm{EXP}=\mathrm{X}^{\mathrm{o}} \mathrm{REF}$ \\
\hline $\begin{array}{l}\text { Does the teacher punish failure in class } \\
\text { performance? }\end{array}$ & 1.71 & 2.68 & -5.521 & $1.42 .10^{-7}$ & $\mathrm{X}^{\mathrm{o}}{ }_{\mathrm{EXP}}<\mathrm{X}^{\mathrm{o}}{ }_{\mathrm{REF}}$ \\
\hline $\begin{array}{l}\text { Is special attention paid to weaker } \\
\text { learners? }\end{array}$ & 3.08 & 2.84 & 1.261 & 0.210 & $\mathrm{X}^{\mathrm{o}} \mathrm{EXP}=\mathrm{X}^{\mathrm{o}} \mathrm{REF}$ \\
\hline $\begin{array}{l}\text { Is special attention paid to gifted } \\
\text { learners? }\end{array}$ & 3.83 & 3.00 & 4.807 & $2.84 .10^{-6}$ & $\mathrm{X}^{\mathrm{o}} \mathrm{EXP}>\mathrm{X}^{\mathrm{o}} \mathrm{REF}$ \\
\hline $\begin{array}{l}\text { Are you encouraged to solve challenging } \\
\text { tasks in your math classes? }\end{array}$ & 3.46 & 2.76 & 3.672 & $1.98 .10^{-4}$ & $\mathrm{X}^{\mathrm{o}} \mathrm{EXP}>\mathrm{X}^{\mathrm{o}} \mathrm{REF}$ \\
\hline $\begin{array}{l}\text { Does the teacher motivate students in } \\
\text { class? }\end{array}$ & 3.22 & 3.40 & -0.685 & 0.494 & $\mathrm{X}^{\mathrm{o}} \mathrm{EXP}=\mathrm{X}^{\mathrm{o}} \mathrm{REF}$ \\
\hline
\end{tabular}

The following table (Table 3) presents the results of the students' answers evaluation within both groups, in entries concentrating on the evaluation of feedback.

Differences between the two groups and the respondents' evaluations only differed in such cases where the teacher allowed their students to be present at the achievement assessment. Statistical significance sides with the experimental group. We may assume, with regards to the fact that discussing hypotheses or discussing formulated conclusions are part of the problem-solving process, that the students largely participated in the evaluation process and would grab the opportunity to express their ideas on the procedures and results of solutions to the problems with their peers.

Another group of entries dealt with the attitudes of the respondents in both groups to the subject of mathematics as a school subject (Table 4).

There are no significant differences between the experimental and control groups' answers. Understanding maths as an important school subject is predominant in the respondents' attitudes. 
Table 3. Respondents' answers evaluation of entries tackling reactions to receiving feedback

\begin{tabular}{|c|c|c|c|c|c|}
\hline Item & $\mathbf{X}^{\mathbf{o}}$ EXP & $\mathbf{X}^{\mathbf{0}}$ REF & $t$ & $\mathbf{P}$ & Comparison \\
\hline $\begin{array}{l}\text { Is students' participation in grading } \\
\text { achievements allowed? }\end{array}$ & 1.94 & 1.50 & 2.409 & $9.20 .10^{-3}$ & $\mathrm{X}^{\mathrm{o}} \mathrm{EXP}>\mathrm{X}^{\mathrm{o}}{ }_{\mathrm{REF}}$ \\
\hline $\begin{array}{l}\text { Do you think yourself successful at } \\
\text { solving maths tasks? }\end{array}$ & 3.33 & 3.56 & -1.304 & 0.195 & $\mathrm{X}^{\mathrm{o}} \mathrm{EXP}=\mathrm{X}^{\mathrm{o}} \mathrm{REF}$ \\
\hline $\begin{array}{l}\text { Are you interested in feedback while } \\
\text { solving mathematics tasks? }\end{array}$ & 3.58 & 3.36 & 1.001 & 0.315 & $\mathrm{X}^{\mathrm{o}} \mathrm{EXP}=\mathrm{X}_{\mathrm{REF}}^{\mathrm{o}}$ \\
\hline
\end{tabular}

Table 4. Respondents' answers evaluation of entries tackling reactions to approaches to the subject of mathematics

\begin{tabular}{|c|c|c|c|c|c|}
\hline Item & $\mathbf{X}^{\mathbf{o}} \mathrm{EXP}$ & $\mathbf{X}^{\mathbf{o}}$ REF & $\mathrm{t}$ & $\mathbf{P}$ & Comparison \\
\hline Is maths a favourite subject of yours? & 3.21 & 3.40 & -0.682 & 0.494 & $\mathrm{X}_{\mathrm{EXP}}^{\mathrm{o}}=\mathrm{X}^{\mathrm{o}} \mathrm{REF}$ \\
\hline Is maths a challenging subject for you? & 2.83 & 2.80 & 0.137 & 0.891 & $\mathrm{X}_{\mathrm{EXP}}^{\mathrm{o}}=\mathrm{X}^{\mathrm{o}} \mathrm{REF}$ \\
\hline $\begin{array}{l}\text { Do you find maths an important sub- } \\
\text { ject? }\end{array}$ & 4.05 & 4.04 & 0.008 & 0.993 & $\mathrm{X}^{\mathbf{o}} \mathrm{EXP}=\mathrm{X}^{\mathrm{o}} \mathrm{REF}$ \\
\hline
\end{tabular}

The absolute frequencies of the respondents' answers to the question: "Why do you think mathematics is taught at school?" are displayed in the following table (Table 5).

No statistically significant difference $\left(\chi^{2}=1.679 ; \mathrm{P}=0.642\right)$ was found in the answers between groups. Unambiguously, the students thought that mathematics is ubiquitous and interweaves with everyday life. The frequency of other answers is principally marginal.

The last group of analysed items involved the students' attitudes to problem-solving. Table 6 displays evaluation of interval entries.

The experiment showed that educational strategy oriented to unconventional ways of problem solving did not give rise to statistically significantly different approaches to solving mathematics problems in the groups of experimental and traditional teaching-learning.

A difference of statistical significance was traced in communication. Solving problems with the use of heuristic strategies requires a different communication model to what is the trend in traditional learning. Mutual communication among learners themselves becomes especially important. Detailed analysis of procedures used to reach solutions to problem tasks is shown in Table 7. 
Table 5. Absolute frequency of reasons why, according to respondents' ideas, maths is taught at schools

\begin{tabular}{lcc}
\hline \multicolumn{1}{c}{ Reasoning } & Experimental class & Control class \\
\hline I can't say, it has to be so. & 0 & 0 \\
\hline To spoil my life. & 0 & 1 \\
\hline I can't say, it may be important. & 2 & 2 \\
\hline $\begin{array}{l}\text { Because maths is everywhere, without it, there } \\
\text { would be no cars, mobiles ... }\end{array}$ & 17 & 18 \\
\hline Because it is in entrance exams. & 1 & 3 \\
\hline
\end{tabular}

Table 6. Evaluating respondents' answers to entries covering students' approaches to maths solving tasks

\begin{tabular}{|c|c|c|c|c|c|}
\hline Item & $\mathbf{X}^{\mathbf{o}}$ EXP & $\mathbf{X}^{\mathbf{o}}{ }_{\text {REF }}$ & $t$ & $P$ & Comparison \\
\hline $\begin{array}{l}\text { Solving maths task, do you suffer from } \\
\text { feelings of anxiety and helplessness? }\end{array}$ & 2.25 & 2.16 & 0.349 & 0.727 & $\mathrm{X}^{\mathrm{o}} \mathrm{EXP}=\mathrm{X}^{\mathrm{o}} \mathrm{REF}$ \\
\hline $\begin{array}{l}\text { Solving maths tasks, do you find com- } \\
\text { munication with peers important? }\end{array}$ & 3.67 & 3.04 & 2.639 & $4.85 .10^{-3}$ & $\mathrm{X}^{\mathrm{o}} \mathrm{EXP}>\mathrm{X}^{\mathrm{o}}{ }_{\mathrm{REF}}$ \\
\hline $\begin{array}{l}\text { How do you find discussions on proce- } \\
\text { dures and solutions to maths tasks? }\end{array}$ & 3.79 & 3.72 & 0.456 & 0.649 & $\mathrm{X}^{\mathrm{o}} \mathrm{EXP}=\mathrm{X}^{\mathrm{o}}{ }_{\mathrm{REF}}$ \\
\hline
\end{tabular}

Table 7. Absolute frequency of answer choices concerning learners' ability to explain the procedure used in a maths task

\begin{tabular}{lcc}
\hline \multicolumn{1}{c}{ Reasoning } & Experimental class & Control class \\
\hline No, I can't do it. & 1 & 2 \\
\hline No, I'm too shy. & 0 & 1 \\
\hline I'm not good enough. & 5 & 3 \\
\hline Yes, if it's a must. & 9 & 13 \\
\hline Yes, I enjoy explaining it to others. & 7 & 5 \\
\hline
\end{tabular}

The prevailing majority of respondents were able to explain the procedure they used to their peers, if asked. However, this ability occurred with the students in both the experimental and control groups. The frequency of answer alternatives suggested does not show a statistically significant difference $\left(\chi^{2}=2.812 ; \mathrm{P}=0.589\right)$. 
Item No. 23 refers to the approaches chosen by the student in the cases of not full comprehension of the problem assigned; the frequency of particular approaches selected is shown in Table 8 .

Table 8. Absolute frequency of answer choices concerning learners' lack of understanding of the task set

\begin{tabular}{lcc}
\hline \multicolumn{1}{c}{ Reasoning } & Experimental class & Control class \\
\hline I wait for what the teacher or peers say. & 3 & 6 \\
\hline I signal I can't understand the problem. & 0 & 2 \\
\hline I try asking my peers. & 13 & 14 \\
\hline $\begin{array}{l}\text { I try to remember if a similar task has already been } \\
\text { taught. }\end{array}$ & 0 & 1 \\
\hline I try to crack it independently. & 6 & 2 \\
\hline
\end{tabular}

In the case that the student did not understand the mathematics problem assigned, the most common procedure used within both groups was asking a schoolmate. Such a procedure can simply be labelled as utilitarian and is viewed as the most efficient from the student's perspective. The best valued approach allows the student to find the solution using their own, individual devices. Nevertheless, such an approach was opted for in the minority of cases. There are no vast differences with statistical significance between the control and experimental groups ( $\chi^{2}=5.869 ; \mathrm{P}=0.209$ ).

Item No. 24 covers the students' answers to the question whether they enjoy solving mathematics problems (Table 9).

Table 9. Absolute frequency of answer choices concerning learners' being keen on solving math problems

\begin{tabular}{lcc}
\hline \multicolumn{1}{c}{ Reasoning } & Experimental class & Control class \\
\hline Absolutely not, it bothers me. & 3 & 1 \\
\hline Not much. & 4 & 3 \\
\hline I don't care, I've got to be at school anyway. & 2 & 7 \\
\hline Not much of a problem. & 11 & 9 \\
\hline Yes, it's fun. & 3 & 5 \\
\hline
\end{tabular}

Similarly, no major statistically significant differences were found within the two groups $\left(\chi^{2}=4.545 ; \mathrm{P}=0.337\right)$. In both groups, "somewhat interested" pre- 
vailed for an answer, which we understand as a positive result. The students also frequently opted for expressing, principally, a rather indifferent attitude to solving maths problems.

Item No. 26 covers possible approaches in the cases where the adopted algorithm to tackle a problem leads to no success. The frequency of the students' choices within answering the question to describe the procedure they used is displayed in Table 10.

Table 10. Absolute frequency of answer choices to algorithm varieties of procedures where the algorithm does not lead to the required goal

\begin{tabular}{lcc}
\hline \multicolumn{1}{c}{ Reasoning } & Experimental class & Control class \\
\hline I give up. & 0 & 0 \\
\hline I ask the teacher or my schoolmates for help. & 4 & 10 \\
\hline I haven't experienced such a situation yet. & 4 & 0 \\
\hline I attempt to reach the solution through trial-and-error. & 9 & 7 \\
\hline I systematically try to find various different ways of solution. & 6 & 8 \\
\hline
\end{tabular}

The preference of individual approaches does not show statistically significant differences in the experimental and control groups $\left(\chi^{2}=7.854 ; \mathrm{P}=0.097\right)$. We consider it to be a positive result that none of the learners gave up their task; the learners attempted at systematic ways of solving a problem by using several ways of handling the problem instead of giving up.

The results of final didactic test were described in detail in Eisenmann, Novotná, Pribyl (a). Our paper compares the students' results in the final (February 2014 - end of experimental teaching) and retention (written eight months after the experiment had finished) tests. Correct solutions to the given problems in both tests were the observed aspect. The rates of correctly solved problems to the total of problems assigned to all the students in the outcome tests was $76 \%$ and $82 \%$ in the achievement test. Comparing individual students' achievements, paired t-test was used (cf., Table 11).

Table 11. t-test for independent sample

\begin{tabular}{lccccccccc}
\hline $\begin{array}{c}\text { Didactic } \\
\text { Test }\end{array}$ & Mean & $\begin{array}{c}\text { Standard Error } \\
\text { of Mean }\end{array}$ & N & $\begin{array}{c}\text { Differ- } \\
\text { ence }\end{array}$ & $\begin{array}{c}\text { Standard Error } \\
\text { of Difference }\end{array}$ & t & sv & p \\
\hline outcome & 6.1 & 0.967906 & & & & & & & \\
\hline achievement & 6.55 & 0.887041 & 20 & -0.45 & 0.944513 & -2.13069 & 19 & 0.046399 \\
\hline
\end{tabular}


Based on the assumption that both picks come from a normal distribution (as suggested by the character of the results), we tested null hypotheses of expected value to be equal. The result is obvious: at the $5 \%$ level of significance, the students obtained considerably better results in the retention test.

\section{Discussion}

In the field of the learners' class activity management in mathematics classes, the major difference was noted between the control and experimental groups. In accordance with the theoretical premises, the largest differences refer to communication patterns applied within lectures.

Problem-based learning accentuates dialogue methods of teaching on a much broader scale, and the methods infiltrate all of the problem-solving procedure steps. Communication among peers was far more common in the experimental group. Changes to the teacher and student roles in problem-based learning are shown in the allowed range of evaluation of education outcomes and the teacher accepts the specificities of their students to a greater extent. The results show that the experimental group students were allowed more independence in solving rather challenging maths problems. The research hypothesis that using educational processes (in mathematics classes) which positively incite individual problem solving are highly appreciated by learners in the experimental class rather than learners in the control group was confirmed. It needs to be stated that, at a more general level, we had expected more differences between the learners' class activity management in both groups than those found. That could be explained by the character of teaching maths, where even traditional class management offers a large scope of problems that, up to a certain level, always consist in the problem-solving approach.

The students' experience with mathematics problems in both group types also show results in the evaluation of other questionnaire items focused on procedures in solving maths problems. It turned out that the students' approaches in the experimental and control groups were identical. The learners prefer to find solutions independently, or they seek solutions in cooperation with peers. Both approaches might be considered required, and if taken from the perspective of the educational process, also required and recommended (cf., e.g., Montague, 2003).

As far as the students' attitude to mathematics education and mathematics teaching is concerned, the control and experimental groups show no statistically 
significant differences. The learners primarily realize the importance of mathematics, not only for their further studies, but also for their everyday life.

Speaking of the evaluation of the didactic test, the result comparing achievement rates in both the outcome and achievement tests is clear: the pupils obtained significantly better results in the achievement test. The development of the learners' ability to solve problems is understandably also supported by more mathematics education in-between. On the other hand, after completing the outcome test, the long-term intensive experimental teaching stopped and we expected the ability to solve problems using heuristic strategies eight months after the end of the experiment to sink slightly. Since the problems in both tests were solved efficiently and with the use of heuristic strategies, we may state that $\mathrm{HO} 2$ was not confirmed.

To conclude, let us point out an interesting relation to the characterization of the pupils in the experimental group, where the CPS structure (Culture of Problem Solving) was used. It involves the structure of internal factors influencing the student's achievement, as described, e.g., in Eisenmann, Novotná, Přibyl ( 2014). Within the frame of a long-term experiment, the pupils in the experimental group were tested in four components of the CPS structure:

1. Intelligence

2. Creativity

3. Reading comprehension

4. Using current knowledge in mathematics

All the components except "intelligence" improved between the starting and finishing points. A slight rise was noted in "reading comprehension", while "creativity" scored a considerable increase, especially in the fields of fluency and flexibility. The detailed results were analysed and interpreted in Eisenmann, Novotná, Přibyl (a). We think the consolidation of the learners' ability to solve problems with the use of heuristic strategies described above may be related to the surge in "reading comprehension" and mainly "creativity".

\section{Conclusions}

The paper has introduced results of a research study which attempted at complex comprehension of problem-based mathematics learning with the use of heuristic strategies, solving mathematics problems at the longitudinal level. The results show that the students mastered heuristic problem-solving strategies in mathematics and were able to implant them efficiently even 8 months after the 
end of the teaching/learning experiment had stopped. Such a result may be linked to the development of fluency and flexibility, proven within the experiment. Sadly, we did not prove a steadier change in the students' approaches to mathematics as a school subject. In the field of pupil learning activity management, differences are to be noticed mainly in the change of the traditional model of pedagogic communication. Above all, it is discussions among the students along with discussions between the students and the teacher that are the core of problem-oriented learning, which responds to the change in roles of learners and teachers in alternatively designed models of learning activity management. The results of this paper show that heuristic methods of solving mathematics problems are beneficial where the educational process is to be made more efficient and leads to students' desirable competence in their own independent and creative problem solving. The experience gained in experimental teaching of mathematics is inspirational for teaching other school subjects, where the analogical concept of scholar-oriented education can be applied.

\section{Acknowledgement}

The research was supported by Czech Science Foundation project P407/12/1939.

\section{References}

Boud, D.; Felletti, G., E. (1997). The Challenge of Problem-based Learning. Second ed. London: Kogan Page.

Eisenmann, P., Novotná, J., Přibyl, J. (2014) Culture of solving problems - one approach to assessing pupils' culture of mathematics problem solving, In: $13^{\text {th }}$ Conference on Applied Mathematics Aplimat 2014, Bratislava, 115-122

Eisenmann, P., Novotná, J., Přibyl, J. (a): The development of a culture of problem solving with secondary students through heuristic strategies and modes, Mathematics Education Research Journal, in print.

Hejný, M., \& Kuřina, F. (2009). Ditě, škola a matematika: Konstruktivistické př́stupy k vyučování. 2. aktualizované vydání. Praha: Portál.

Jeřábek, J., Lisnerová, R., Smejkalová, A., \& Tupý, J. (Eds.). (2013). Rámcový vzdělávací program pro základní vzdělávání: (verze platná od 1.9. 2013) úplné znění upraveného RVP ZV. Praha: MŠMT.

Jirotková, D. (2010). Cesty ke zkvalitňování výuky geometrie. Praha: Univerzita Karlova, Pedagogická fakulta.

Kanakis, C., D.; Chatzidimou, D. (1980). Die praktische Relevanz des sokratischen Prinzips. Frankfurt a. M.: Lang. 
Kuřina, F. (2011). Matematika a řešení úloh. České Budějovice: Jihočeská univerzita v Českých Budějovicích, Pedagogická fakulta.

McInerney, D., M.; McInerney, V. (1998). Educational Psychology: Constructing Learning. Sydney: Prentice Hall.

Montague, M. (2003). Solve it: A mathematical problem - solving instructional program. Reston, VA: Exceptional Innovations.

Pajares, F., \& Kranzler, J. (1995). Self-Efficacy Beliefs and General Mental Ability in Mathematical Problem-Solving. Contemporary Educational Psychology, 20(4), 426-443.

Silver, E. A. (1985). Teaching and Learning Mathematical Problem Solving: Multiple Research Perspectives. Hillsdale, NJ: Lawrence Erlbaum Associates, Inc., Publishers.

Stehlíková, H. (ed.) (2007). Náměty na podnětné vyučování v matematice. Praha: Univerzita Karlova, Pedagogická fakulta. 